JRIT

14,3

310

Received 23 January 2021

Revised 22 April 2021

3 May 2021

Accepted 17 July 2021

\section{Students' perceived benefits, adoption intention and satisfaction to technology-enhanced learning: examining the relationships}

\author{
Pushkar Dubey and Kailash Kumar Sahu \\ Department of Management, \\ Pandit Sundarlal Sharma (Open) University Chhattisgarh, Bilaspur, India
}

\begin{abstract}
Purpose - Providing quality education with the help of technologies in order to create global competitiveness among the students is the current trend in the education field. This research attempts to investigate following objectives: (1) the effect of students' perceived benefits and adoption intention of technology-enhanced learning (TEL) on their satisfaction; (2) the effect of students' perceived benefits of TEL on their adoption intention of TEL; (3) the mediating and moderating effect of students' perceived benefits of TEL in the link between students' adoption intention and satisfaction to TEL.

Design/methodology/approach - The primary data were collected from 600 undergraduate and postgraduate students, particularly those who are using TEL for at least one year. The authors used purposive sampling technique with "criterion variable".

Findings - Results indicated that students' perceived benefits and adoption intention of TEL have significant and positive influence on their satisfaction. Direct effect was also found between perceived benefits and adoption intention of students. Authors also concluded that mediating and moderating effect of students' perceived benefits of TEL in the link between students' adoption intention and satisfaction for TEL was found significant and positive.
\end{abstract}

Originality/value - There is a huge lack of empirical studies available in the knowledge domain explaining the significance and implication of TEL in higher education in the state of Chhattisgarh, India.

Keywords Students' perceived benefits, Adoption intention, Student satisfaction, Technology-enhanced learning, Higher education, Academic performance

Paper type Research paper

\section{Introduction}

COVID-19 has impacted all spheres of life so as the educational institutions. Globally, all educational institutions are striving to get into the students' life in order to provide all the necessary learning services and become first in the online learning platforms. World Health Organization (WHO) has also announced that COVID-19 will be there among us for a long time (Jagannath, 2020) as the other diseases such as polio, cancer and so on, and this made the biggest challenge for all the educational institutions to transform themselves from traditional learning to technology-based learning. However, it is not new that learners are going to study or learn something using technology as the new-generation learners have high adoption intention of technologies. Digital devices and several other applications such as YouTube, Facebook and other chatting apps and so on have dynamically transformed people's way of living including social activities, communications and learning environment (Tiyar and

(C) Pushkar Dubey and Kailash Kumar Sahu. Published in Journal of Research in Innovative Teaching \& Learning. Published by Emerald Publishing Limited. This article is published under the Creative CommonsAttribution (CC BY 4.0) licence. Anyone may reproduce, distribute, translate and create derivative worksof this article (for both commercial and non-commercial purposes), subject to full attribution to theoriginal publication and authors. The full terms of this licence may be seen at http:// creativecommons.org/licences/by/4.0/legalcode
Journal of Research in Innovative Teaching \& Learning Vol. 14 No. 3,202 pp. $310-328$ Emerald Publishing Limited 2397-7604

DOI 10.1108/JRIT-01-2021-0008

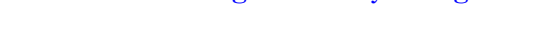


Khoshsima, 2015). The increased tendency towards online learning materials with different technologies clearly indicates that various learning systems assist students in their learning process which eventually improves their academic performance (Chunwijitra et al., 2013). However, higher education is now more focussing to provide higher order skills and experiences which requires a major change in communication and learning environment (Thomas, 2011).

Technology-enhanced learning (TEL) is the need of the hour, and in this regard, higher education institutions (HEIs) have started incorporating technology-based learning in their curricula considering its importance in the academic performance (Bhuasiri et al., 2012) and developing higher order skills such as analysing, critical thinking and problem-solving ability. In today's competitive environment, it becomes imperative for learners to complete their higher education with latest knowledge and technologies in their respective field which they will need in their professional career (King and Boyatt, 2014). However, introducing information and communication technology (ICT) into HEIs ensures neither adoption intention among students nor usage of such technologies. In addition, learners will not be able to take benefits from these technologies, unless they intend to adopt and use them as the previous studies suggest that effectiveness and efficiency of technology-enhanced learning lie on the learners' adoption intention towards modern technologies (Chang and Tung, 2008; Park, 2009; Tarhini et al., 2014).

Bhuasiri et al. (2012) investigated critical success factors of technology-based learning with experts such as faculty, researchers and ICT experts in developing countries. The top factors were found, that is, perceived benefits, adoption intention, programme flexibility and clear direction. The researchers concluded that people in developing countries have less familiarity with technologies which makes it critical for technology-based learning for such learners.

However, looking at the trend, the usage of technology has been increasing continuously, according to Wadhwani and Gankar (2020), technology-based learning market size was 200bn in 2019 and is expected to grow at over 8\% CAGR (Compound Annual Growth Rate) between 2020 and 2026. But, due to the COVID-19 impact, the usage of online learning technologies would increase faster than the calculative figure.

Undoubtedly, technology is proven significant to enhance the learning process and productivity of students (Al-Hariri and Al-Hattami, 2017), and the present study attempts to investigate the effect of students' perceived benefits and adoption intention of TEL on their satisfaction enrolled in higher education in Chhattisgarh state. It also focusses to examine the mediating and moderating effect of students' perceived benefits of TEL in the link between students' adoption intention and satisfaction in the higher education of Chhattisgarh.

\section{Literature review}

Growing trend can be seen in the education institutions in the usage of ICTs in order to enhance the knowledge and skills of students as demanded in the 21st century. Understanding the effect of ICT in the workplace and everyday life, educational institutions are restructuring their curricula and other facilities in order to cope with the current technologies in teaching and learning process. Effective adoption of technologies is required in this restructuring process in order to provide knowledge of specific subject areas, to foster meaningful learning and to increase the professional productivity (Tomei, 2005). TEL supports the teaching-learning process with the usage of different technologies. Prior studies (Sife et al., 2007; Demiray, 2011) have highlighted the significance of technology-based learning in the improvement of teaching and learning in higher education. Sandars (2012) also discussed about the importance and usage of TEL in today's educational environment. The researcher concluded that technology has the potential to develop an international viewpoint related to teaching and learning.
Technologyenhanced learning 
JRIT

14,3

312

According to Alfraih and Alanezi (2016), traditional learning is being transformed into electronic learning as it reinforces the teaching-learning process and helps to understand different concepts easily. TEL can be defined as the delivery of learning materials and methods using information technologies to teach, learn or acquire knowledge anytime from anywhere (Turban et al., 2015). It offers benefits to learners to have flexibility and convenience in their learning process irrespective of their time and location. Even learners have the opportunity to acquire and disseminate knowledge digitally (Tetteh, 2016).

Garrison (2011) also revealed that TEL provides learners to learn from their home or workplaces, and this reportedly reduces the time and cost of teaching and learning by $50-70 \%$. Learners are free to adjust their time and location including the learning materials; meanwhile the learners can find the best instructors to deliver the quality lectures. The lectures can be attended by numerous learners at the same time with an opportunity to ask queries to experts. It also allows experts to check progress of each learners. However, technology-based learning is also helpful to them who do not want to attend face-to-face classes or do not have time to attend such classes. Despite these benefits and others that are not discussed above, if the learners do not adopt technology-based learning, they would be deprived from such a beneficial tool (Tarhini et al., 2017). Therefore, it can be said that the success of technology-based learning lies on the students' adoption intention towards such tools (Al-Qirim et al., 2018).

Evidently, due to the benefits and flexibility, technology-based learning helped in reducing learners' dropout rates (Turban et al., 2015), while some studies suggest that it records high dropout rates than the face-to-face programmes (Dodge et al., 2009; Patterson and McFadden, 2009). Many learners stop using technology-based learning courses after preliminary experiences (Dutton and Perry, 2002; Sun et al., 2008; Aixia and Wang, 2011). TEL success is clearly dependent on the students' adoption intention, from which they would be benefitted. Many universities have established technology-based learning environment in their higher education institutes, but could not get success due to some challenges (Baloyi, 2014; Kisanga, 2016; Queiros and de Villiers, 2016; Makokha and Mutisya, 2016; Chawinga and Zozie, 2016; Al-Azawei et al., 2016). However, several factors such as students' perceived benefits and adoption intention of electronic learning systems create a positive effect on learners' satisfaction, and it is also measurable even after the learning activity (Sun et al., 2008; Hui et al., 2008; Lee and Lehto, 2013; Del Barrio et al., 2013).

Previous researchers stated that TEL benefitted the educational community (Beetham and Sharpe, 2013). For instance, TEL facilitates learners to explore online educational content in their own space and time (De Jong and Van Joolingen, 1998) which makes the learners in charge of their own learning, instead of being completely dependent on teachers (Saye and Brush, 2007), and learning gap can also be fulfilled using TEL (Becker et al., 2017). In terms of whether TEL encourages the improved learning outcomes to learners, researchers found certain positive results with academic benefits (Henderson et al., 2015; Heflin et al., 2017). Further, students' perceived benefits were found to be significant with adoption intention of technology-based learning (Park, 2009; Cheng, 2011; Hair et al., 2013; Tarhini et al., 2014; Lee and Hsiao, 2014). Perceived benefits reflect that using technology for learning will benefit them in future. Thus, TEL is relatively more beneficial to the learners (Fonseca et al., 2014), but there are studies that showed negative effects of using TEL (Jacobsen and Forste, 2011) such as deterioration of interests related to reading and writing among students, distorted relations between teachers and students, dehumanizing learning environment and isolation issues when using technologies (Alhumaid, 2019).

\subsection{What is technology-enhanced learning (TEL)?}

The term technology-enhanced learning can be described as its application in the field of teaching and learning. It is a broad category which is not defined specifically, but, in short, 
TEL can be defined as the combination of educator's practices regarding teaching and learning with appropriate usage of technologies to maximize the students' outcomes and experiences (Cullen, 2018). In general, TEL is understood as learning which occurs through the application of ICT and Internet-based educational technology. TEL is also termed as technology-assisted learning, technology-based learning, e-learning and mobile learning.

\subsection{Significance of technology-enhanced learning in higher education}

TEL is significant for many reasons (Cullen, 2018). Firstly, TEL can facilitate numerous benefits for universities as well as students (Bhuasiri et al., 2012). It helps universities in reducing significant costs invested in the physical teaching and learning infrastructures (Arbaugh, 2005). Secondly, TEL also helps universities in becoming more digitized and contributing to build digital learning society which offers knowledge and learning in a very simple and fast way to the learners at anytime and anywhere using Internet technologies (Taylor, 2007). And thirdly, TEL facilitates universities to integrate their services into globallevel educational learning environment (Lee, 2010). Specifically, international cooperation and links in the field of education provide numerous opportunities for online learning beyond the boundaries of one country. For instance, joint training programme with a foreign university in which domestic students are not required to go abroad, instead they can avail full training and services offered by the foreign university with the help of Internet-enabled technologies. In reality, it is now impossible to survive in the world without the presence of technologies. Therefore, it becomes important that everyone has to learn how to use technologies effectively. Arguably, being computer literate is now more significant than some traditional skills taught earlier in educational institutes (Cullen, 2018).

\subsection{Operational definitions}

(1) Students' perceived benefits of TEL

Perceived benefits refer to the degree to which a learner thinks that using TEL will be beneficial for his/her study in terms of time, effort and cost. Bennett and Bennett (2003) stated that students' perceived benefits are the degree in which the teachers compare new innovation with existing one and also talk about the benefits and costs of an adopted new technology (Rogers, 1995).

(2) Students' adoption intention of TEL

Adoption intention term can be defined as individual's approach to engage into certain behaviour (Institute of Medicine, 2002). According to Fishbein and Ajzen (1975), intention is a subjective likelihood in order to perform certain tasks by an individual.

\section{(3) Student satisfaction}

According to Sweeney and Ingram (2001), student satisfaction is defined as the pleasure and success which they receive from the learning environment. There are several factors which also influence satisfaction to students such as teachers' knowledge and performance, positive learning environment, effective communication, interaction in the teaching-learning process, the prestige and value of the institution (Wu et al., 2010).

\subsection{Research questions}

The research questions are:

$R Q 1$. What effect do students' perceived benefits and adoption intention have on satisfaction to TEL in HEIs of Chhattisgarh state?
Technologyenhanced learning 
JRIT

14,3

\section{4}

Figure 1.

Conceptual framework of the study
RQ2. What effect do students' perceived benefits of TEL have on adoption intention of TEL in HEIs of Chhattisgarh state?

RQ3. Whether students' perceived benefits of TEL play as moderating and mediating role between students' adoption intention and satisfaction to TEL in HEIs in Chhattisgarh state?

\section{Methodology}

3.1 Conceptual frameworks of the study

There are a few studies that explained the relationship of students' perceived benefits and adoption intention on satisfaction to technology-based learning (Sun et al., 2008; Hui et al., 2008; Lee and Lehto, 2013; Del Barrio et al., 2013) which is congruent with the objectives of the present study as shown in the following conceptual framework (see Figure 1).

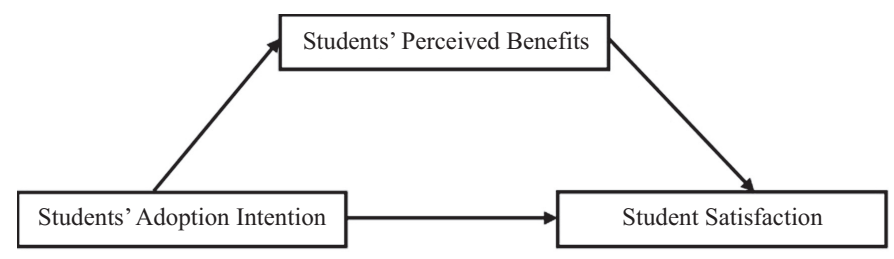

\subsection{Research hypotheses}

The hypotheses of the study are as follows:

H1. Students' perceived benefits of TEL would positively influence their satisfaction.

H2. Students' adoption intention of TEL would positively influence their satisfaction.

H3. Students' perceived benefits of TEL would positively influence students' adoption intention of TEL.

H4. Students' perceived benefits of TEL would positively mediate the link between students' adoption intention and satisfaction to TEL.

H5. Students' perceived benefits of TEL would positively moderate the link between students' adoption intention and satisfaction to TEL.

\subsection{Sampling and data collection}

The primary data were collected using purposive sampling technique with "Criterion Sampling" (Palys, 2008). Respondents were finalized with certain specifications, that is, using TEL by undergraduate or postgraduate students, enrolled in non-technical courses in any government or private university/college in Chhattisgarh state, for at least one year. Sample size for the study was finalized as 600. The primary data were collected during AprilNovember 2019 (see Table 1).

\begin{tabular}{|c|c|c|c|c|c|c|}
\hline \multicolumn{2}{|c|}{ Govt. College } & \multicolumn{2}{|c|}{ Private college } & \multicolumn{2}{|c|}{ Semi govt. College } & Total respondents \\
\hline 240 & & & & & & \\
\hline $\begin{array}{l}\text { Male } \\
66\end{array}$ & $\begin{array}{l}\text { Female } \\
174\end{array}$ & $\begin{array}{c}\text { Male } \\
102\end{array}$ & $\begin{array}{c}\text { Female } \\
198\end{array}$ & $\begin{array}{c}\text { Male } \\
32\end{array}$ & $\begin{array}{c}\text { Female } \\
28\end{array}$ & 600 \\
\hline
\end{tabular}

Table 1.

Description of sample 


\subsection{Research instrument and scale validation}

Adoption of the right tool is the prime necessity for obtaining the correct form of data from the respondents. Development, selection and validation of scale are a systematic process in research which leads to the formulations of standard tools and that are considered appropriate for data collection. The present study also followed the same process where the authors adapted the constructs from previous studies. After identification and development of the measurement items, it was sent to four subject experts for further examination for scrutiny and content validity. After getting a positive response from subject experts, authors conducted a pilot study taking a sample size of 50 respondents to check the content creation. The content creation was found to be adequate and suitable to respond by the participants (see Table 2).

The present study employed partial least square confirmatory factor analysis for scale validation with the help of Smart PLS 3 (trial version). It is a structural equation-based methodology that deploys component-based approach for estimating the parameters. The entire process of scale validation is done with two steps, that is, reliability measures and validity measures including convergent validity and discriminant validity.

Table 3 shows the measures with item loading. The value of $t$ statistics for all the items was above 1.96 and was significant, thus each of the items had significant contribution in making the construct. From the result of factor analysis of the measurement items, it can be observed that the factor loading for each of the items of the construct was found to be $>0.5$ (Hulland, 1999; Truong and McColl, 2011), confirming that each of the items had significant loading value and thus contributed to the formation of their respective constructs.

3.4.1 Reliability measures. Internal consistency refers to the extent to which the items in a test measure the same construct and can be accessed through Cronbach's alpha (Nunnally, 1978). The assessment of Cronbach's alpha for all the individual constructs was found above 0.7 . The value of $\alpha \geq 0.7$ suggests that the construct is internally consistent and fairly reliable (Nunnally, 1978). Table 3 depicts the value of Cronbach's alpha for students' perceived benefits $\alpha=0.707$, students' adoption intention $\alpha=0.727$ and student satisfaction $\alpha=0.811$.
Technologyenhanced learning
Students' perceived benefits

1. Using the free resources such as e-libraries helped me to save Adapted from Tarhini et al. (2017) money and effort

2. Using emails to communicate with other student groups helped me to save my expense and effort

3. Use of Internet is reasonably priced

4. Use of Internet is a good value for the money

\section{Students' adoption intention}

1. I will use the e-learning platform on a regular basis in the future

2. I will continue using e-learning platform in order to fulfil my future needs

3. I will strongly recommend others to use the e-learning platform

Student satisfaction

1. Use of e-resources improves my ability to integrate information

2. I am satisfied with the learning flexibility of e-learning system

3. I am satisfied with the online learning environment

4. E-learning systems allow me to accomplish learning tasks more quickly

5. Using e-learning system increases my productivity
Adapted from Ajjan and Hartshorne (2009) and Roca et al. (2006)

Adapted from Lin et al. (2018) and Tarhini et al. (2017)
Table 2.

Theoretical construct and measurement scale 


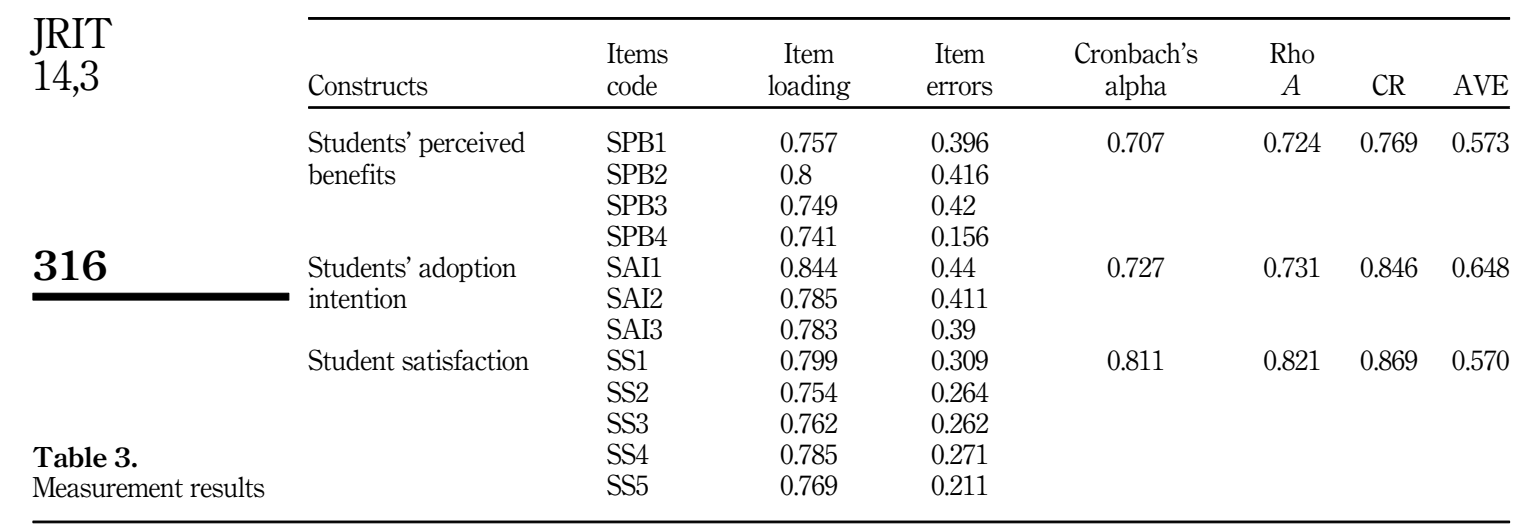

The reliability measure can also be accessed through the value of Rho A. The value of Rho $A \geq 0.7$ is also considered as fair measure of reliability. Table 3 depicts the value of $\mathrm{R}$ ho $\mathrm{A}$ for students' perceived benefits 0.724 , students' adoption intention 0.731 and student satisfaction 0.821 . Thus, the construct confirms the reliability measures of the data for the study.

3.4.2 Validity measures. 3.4.2.1 Convergent validity. The convergent validity is the degree to which multiple items to measure the same concept are in agreement (Fornell and Bookstein, 1982; Barclay et al., 1995). The value of composite reliability (CR) $\geq 0.7$ suggests internal consistency reliability of the measures used in the study (Bagozzi and Yi, 1988; Hair et al., 2010). Table 3 depicts the value of CR for students' perceived benefits 0.769, students' adoption intention 0.846 and student satisfaction 0.869 indicating high degree of $\mathrm{CR}$ of scale.

The average variance extracted (AVE) is the determinant of convergent validity of the scale. It signifies the amount of variance captured by a construct from each scale. The value of AVE $\geq 0.5$ provides fair evidence for the convergent validity measures for the construct (Hu et al., 2004; Henseler et al., 2009). Table 3 depicts the value of AVE for students' perceived benefits 0.573 , students' adoption intention 0.648 and student satisfaction 0.570 . Thus, all the constructs are fairly good in terms of convergent validity measures.

3.4.2.2 Discriminant validity. Discriminant validity signifies that the constructs are independent of each other. The discriminant validity signifies low correlation between intended construct measurement and to that of the other constructs in the study (Cheung and Lee, 2010; Hair et al., 2010). It means that the measures are from the own constructs (Fornell and Larcker, 1981). In partial least square measurement, it signifies comparison of squared correlation between the construct and variance extracted for a construct (Komiak et al., 2004; Henseler and Chin, 2010). The value of discriminant validity measures shown in Table 4 elucidates values of students' adoption intention 0.805 , students' perceived benefits 0.687 and

Table 4.

Discriminant validity

\begin{tabular}{lccc}
\hline Discriminant validity (Fornell-Larcker criterion) & $\begin{array}{c}\text { Students' adoption } \\
\text { intention }\end{array}$ & $\begin{array}{c}\text { Students' perceived } \\
\text { benefits }\end{array}$ & $\begin{array}{c}\text { Student } \\
\text { satisfaction }\end{array}$ \\
\hline Constructs & 0.805 & & \\
$\begin{array}{l}\text { Students' adoption } \\
\text { intention, }\end{array}$ & 0.583 & 0.687 & \\
$\begin{array}{l}\text { Students' perceived } \\
\text { benefits }\end{array}$ & 0.748 & 0.614 & 0.755 \\
Student satisfaction & & &
\end{tabular}


student satisfaction 0.755 signifies higher value than that of the construct correlation and therefore can be said to have a satisfactory measurement model (Henseler and Chin, 2010).

\subsection{Data analysis}

AMOS v25 (licensed), SPSS v25 (licensed) and Smart-PLS 3 (trial version) have been used for analysing the primary data for the present study.

\section{Analysis and results}

\subsection{Testing of $\mathrm{H} 1$ and $\mathrm{H} 2$}

Hierarchal multiple regression (step-wise) was run to determine whether students' adoption intention and perceived benefits of TEL have effect on student satisfaction. Table 5 depicts the details of the regression model with student satisfaction to TEL as a criterion variable. In order to meet the assumption of multiple regression, partial regression plots and a plot of scrutinized residuals were assessed to check the linearity. The value of Durbin Watson statistics was 1.944 which indicated the independence of residuals. There was no multicollinearity in the data as all the tolerance values were greater than 0.1 , variance inflation factor (VIF) found to range from 1.000 to 1.295, which was distant from 1.0-3.0, the criteria that may indicate multicollinearity concern (O'brien, 2007). It means that multicollinearity found significant correlation between all predicting variables. The value of cook's distance is above 1 and the data was approximate normal accessed by Q-Q plot. The results of the hierarchical multiple regression analysis for the composite scores of the independent variables are presented in Table 5 and Figure 2.

In model 1 , students' adoption intention of TEL made significant contribution in variation of student satisfaction, $(F(1.598)=741.709, p<0.01)$ and explained $55.4 \%$ of the variance in student satisfaction $\left(R=0.744, R^{2}=0.554\right)$. The standardized beta value $(\beta=0.744$, $t=27.234, p<0.01$ ) indicated significant positive association between predictor students' adoption intention and satisfaction to TEL.

In model 2, students' perceived benefits of TEL made significant contribution in variation of student satisfaction $(\Delta F(1.597)=34.604, p<0.01)$. The introduction of factor students' perceived benefits of TEL explained additional $2.4 \%$ variance in student satisfaction with

\begin{tabular}{|c|c|c|c|c|c|c|}
\hline \multirow[b]{2}{*}{ Predictors } & \multicolumn{3}{|c|}{ Model 1} & \multicolumn{3}{|c|}{ Model 2} \\
\hline & $\beta$ & $t$ & VIF & $\beta$ & $t$ & VIF \\
\hline $\begin{array}{l}\text { Students' adoption intention } \\
\text { Students' perceived benefits }\end{array}$ & 0.744 & 27.234 & 1.00 & 0.178 & 5.883 & 1.295 \\
\hline$R$ & & 0.744 & & & 0.76 & \\
\hline$R^{2}$ & & 0.554 & & & 0.578 & \\
\hline$\Delta R^{2}$ & & 0.554 & & & 0.024 & \\
\hline$\Delta F$ & & 8) $=741$ & & & $(1.597)=3$ & \\
\hline
\end{tabular}

Technologyenhanced learning

Table 5.

Result of hierarchical multiple regression analysis

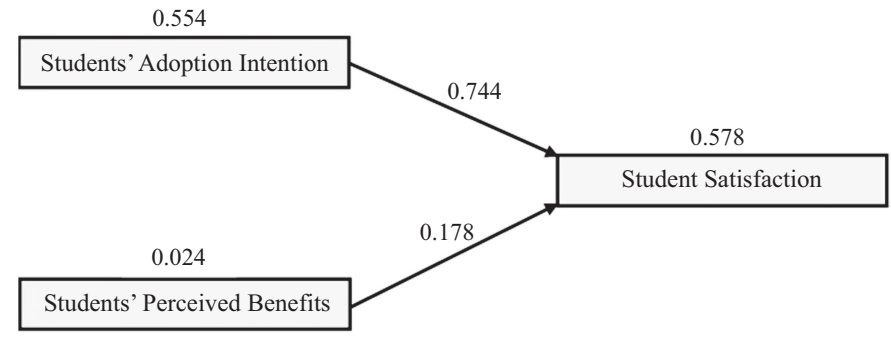

Figure 2. Model specification for students' adoption intention and perceived benefits of TEL on student satisfaction 
JRIT

14,3

\section{8}

overall $57.8 \%\left(R=0.76, \Delta R^{2}=0.024\right)$. The predictor of students' perceived benefits of TEL was found to have significant positive association $(\beta=0.178, t=5.883, p<0.01)$ with student satisfaction.

Result indicates that the explaining percentage of all predictors was $57.8 \%$; this total of the variance included $55.4 \%$ for students' adoption intention of TEL and $2.4 \%$ for students' perceived benefits of TEL (see Figure 2).

\subsection{Testing of $\mathrm{H} 3$}

A linear regression was run to find the effect of students' perceived benefits of TEL on students' adoption intention of TEL. To assess linearity scatter plot of students' adoption intention against perceived benefits of TEL with superimposed regression line was plotted. Visual inspection of the plots indicated linear relationship between the variables under study. There were homoscedasticity and normality of residuals. Students' perceived benefits of TEL significantly predicted students' adoption intention of TEL, $F(1.598)=176.308, p<0.001$, accounting for $47.7 \%$ of variation in adoption intention of students. The adjusted $R^{2}=22.6 \%$ was a medium size effect (Cohen, 1988). The predicted regression equation was students' adoption intention of TEL $=8.175+(0.254$ X Students' perceived benefits of TEL) (see Tables 6, 7 and 8, Figure 3).

Table 6.

Model summary

\begin{tabular}{cccccc} 
Model & $R$ & $R$-Square & Adjusted $R$ square & Std. error of the estimate & Durbin-Watson \\
\hline 1 & $0.477^{\mathrm{a}}$ & 0.228 & 0.226 & 2.07208 & 1.644
\end{tabular}

Note(s): a. Predictors: (Constant), students' perceived benefits (SPB)

b. Dependent variable: Students' adoption intention (SAI)

\begin{tabular}{llrrrrr}
\hline Model & & Sum of squares & df & Mean square & $F$ & Sig \\
\hline 1 & Regression & 756.985 & 1 & 756.985 & 176.308 & $0.000^{\mathrm{b}}$ \\
& Residual & 2567.534 & 598 & 4.294 & & \\
& Total & 3324.518 & 599 & & &
\end{tabular}

Table 7.

Note(s): a. Dependent variable: Students' adoption intention (SAI)

ANOVA results

b. Predictors: (Constant), students' perceived benefits (SPB)

\begin{tabular}{|c|c|c|c|c|c|c|c|}
\hline \multirow[b]{2}{*}{ Model } & \multicolumn{2}{|c|}{$\begin{array}{l}\text { Un-standardized } \\
\text { coefficients }\end{array}$} & \multirow{2}{*}{$\begin{array}{c}\text { Standardized } \\
\text { coefficients } \\
\beta\end{array}$} & \multirow[b]{2}{*}{$t$} & \multirow[b]{2}{*}{ Sig } & \multicolumn{2}{|c|}{$\begin{array}{l}\text { Collinearity } \\
\text { statistics }\end{array}$} \\
\hline & $\beta$ & Std. error & & & & Tolerance & VIF \\
\hline (Constant) & 8.175 & 0.302 & & 27.042 & 0.000 & & \\
\hline SPB & 0.254 & 0.019 & 0.477 & 13.278 & 0.000 & 1.000 & 1.000 \\
\hline
\end{tabular}

Table 8.

Coefficient values

\section{Figure 3.}

Model specification for students' perceived benefits on students' adoption intention of TEL

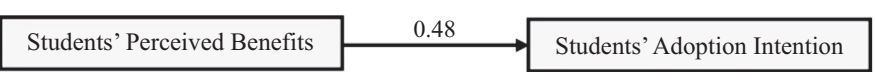




\subsection{Testing of $\mathrm{H} 4$}

In order to find the mediating effect of students' perceived benefits of TEL as a link between students' adoption intention and satisfaction to TEL, process macro in SPSS developed by Andrew Hayes was used (Hayes, 2013) (see Table 9).

Regression analysis was used to investigate whether students' perceived benefits (SPB) of TEL mediates the effect of students' adoption intention (SAI) on their satisfaction to TEL. Result indicated that students' adoption intention of TEL was a significant predictor of students' perceived benefits positively, $\beta=0.897, \mathrm{SE}=0.0676, t=13.2781, p<0.05$, and that students' perceived benefits of TEL were also a significant predictor of student satisfaction (SS), $\beta=0.1537, \mathrm{SE}=0.0261, t=5.8825, p<0.05$. This result supports the mediational hypothesis. After controlling for the mediator, students' adoption intention of TEL was found a significant predictor of student satisfaction, $\beta=1.07, \mathrm{SE}=0.0491, t=21.79, p<0.05$ and is
Technologyenhanced learning

Process procedure for SPSS version 3.4

Written by Andrew F. Hayes, Ph.D. www.afhayes.com

Documentation available in Hayes (2013). www.guilford.com/p/hayes3

Model: 4

$\mathrm{Y}: \mathrm{SS}$

$\mathrm{X}$ : SAI

M: SPB

Sample size: 600

OUTCOME variable: SPB

Model summary

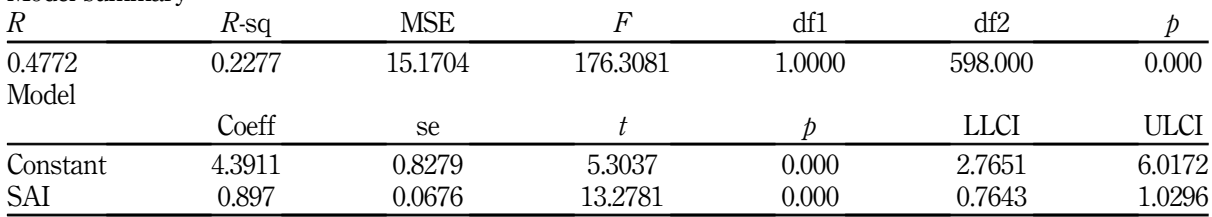

OUTCOME variable: SS

Model summary

\begin{tabular}{lcccccr}
$R$ & $R$-sq & MSE & $F$ & df1 & df2 & $p$ \\
\hline 7603 & 0.5781 & 6.192 & 408.9964 & 2 & 597 & 0.000 \\
Model & & & & & & ULCI \\
\hline & Coeff & se & $t$ & $p$ & LLCI & 3.6296 \\
\hline Constant & 4.6925 & 0.5412 & 8.6698 & 0.000 & 0.9736 & 1.1665 \\
SAI & 1.0701 & 0.0491 & 21.790 & 0.000 & 0.1024 & 0.2050 \\
SPB & 0.1537 & 0.0261 & 5.8825 & 0.000 & & \\
\hline
\end{tabular}

Direct and indirect effects of $X$ on $Y$

Direct effect of X on Y

\begin{tabular}{rccccr} 
Effect & se & $t$ & $p$ & LLCI & ULCI \\
\hline 1.0701 & 0.0491 & 21.790 & 0.000 & 0.9736 & 1.1665 \\
\hline
\end{tabular}

Indirect effect(s) of $\mathrm{X}$ on $\mathrm{Y}$

SPB

Effect

BootSE

BootLLCI
0.0607

BootULCI

0.3604

Table 9 Mediation analysis 


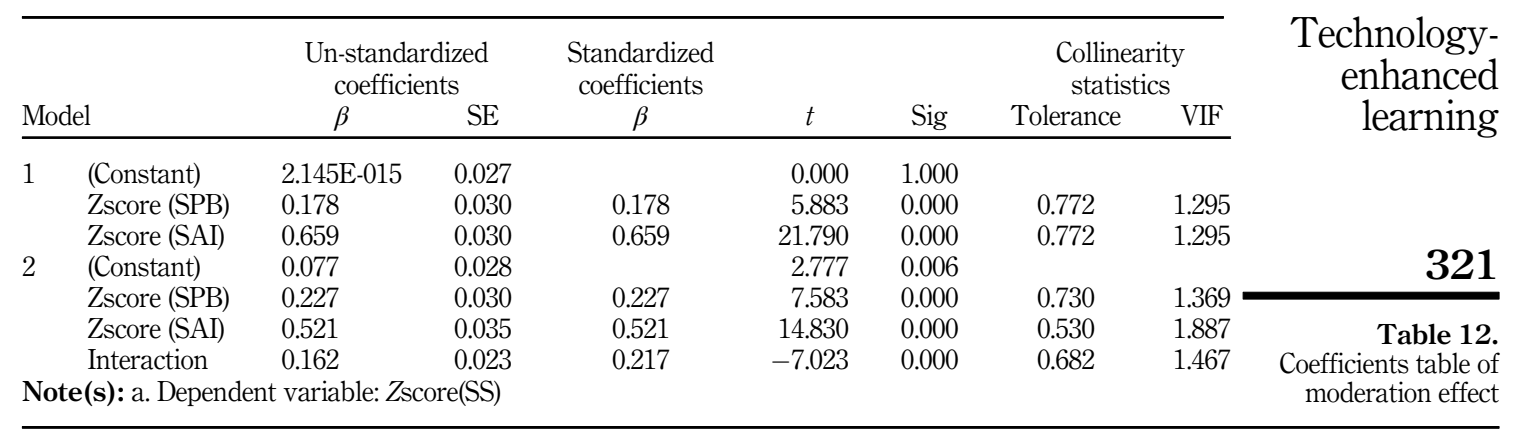

\begin{tabular}{|c|c|c|c|}
\hline Hypothesis & Statement & Results & \\
\hline H1 & Students' perceived benefits of TEL would positively influence their satisfaction & Confirmed & \\
\hline $\mathrm{H} 2$ & Students' adoption intention of TEL would positively influence their satisfaction & Confirmed & \\
\hline H3 & $\begin{array}{l}\text { Students' perceived benefits of TEL would positively influence students' adoption } \\
\text { intention of TEL }\end{array}$ & Confirmed & \\
\hline H4 & $\begin{array}{l}\text { Students' perceived benefits of TEL would mediate the link between students' } \\
\text { adoption intention and satisfaction to TEL }\end{array}$ & Confirmed & \\
\hline H5 & $\begin{array}{l}\text { Students' perceived benefits of TEL would moderate (interact) the link between } \\
\text { students' adoption intention and satisfaction to TEL }\end{array}$ & Confirmed & $\begin{array}{l}\text { Outcomes of the } \\
\text { proposed hypotheses }\end{array}$ \\
\hline
\end{tabular}

\section{Findings and discussion}

(1) The result of the first hypothesis test indicated that students' perceived benefits of TEL positively and significantly influenced student satisfaction and the hypothesis is accepted. The outcome was found to be consistent with the previous research studies (Al-Hawari and Mouakket, 2010; Ifinedo, 2016). Thus, it can be concluded that perceived benefits of TEL in comparison with the traditional learning are found more productive and performance-based medium of learning among students. Students found themselves more connected with TEL which further enhances their academic performance and satisfaction.

(2) The outcome of the second hypothesis test revealed that students' adoption intention of TEL positively and significantly influenced student satisfaction and the hypothesis is accepted. The study outcome was found to be consistent with the previous studies (Davis et al., 1989; Seddon, 1997; Limayem and Cheung, 2008; Stone and Baker-Eveleth, 2013; Cheng, 2014; Tang et al., 2014; Liao et al., 2015; Chen et al., 2015; Ifinedo, 2016). Thus, it can be concluded that higher intentions of the students to take online medium of learning would result in better understanding of learning materials and, then, higher satisfaction.

(3) The outcome of the third hypothesis test revealed that students' perceived benefits of TEL positively and significantly influenced their adoption intention of TEL and hypothesis is accepted. Similar outcomes were found in previous studies (Ong and Lai, 2006; Lee et al., 2011; Chu and Chen, 2016; Salloum and Shaalan, 2018). Thus, it can be said that students' perceived benefits for online learning would generate higher intention to adopt online learning. Considering the various benefits such as several quality learning materials, less cost, own time and place including their own 
JRIT

14,3

322 learning pace, these benefits would make them to adopt technology-based learning for their study.

(4) The result of the fourth hypothesis test concluded that students' adoption intention of TEL was associated with student satisfaction and that were partially mediated by students' perceived benefits of TEL and the hypothesis is accepted. Thus, it can be derived that various benefits offered by TEL would create positive intention to adopt technology for the improvement in their academics which would create higher level of satisfaction among learners.

(5) The outcome of the fifth hypothesis test revealed that the interaction effect (moderation) of students' perceived benefits in the effect of students' adoption intention on satisfaction was found to be significant and the hypothesis is accepted. Thus, it can be concluded that combining the component of students' perceived benefits with adoption intention to use online learning can yield higher satisfaction among the students. It is, therefore, required to make the students aware about the advantages of online learning practices and create adoption intention of TEL to achieve the higher level of student satisfaction.

\section{Contributions of the study}

The present study contributes to the theory and practice, specifically in Chhattisgarh higher education, where people are less aware of technologies or less number of people are using technologies for learning purposes. At the times of COVID-19, where educational institutions are struggling to know more about their potential learners, this study provides knowledge about the students' adoption intention and perceived benefits and its relation to learners' satisfaction to TEL. It also showed the relationship of students' perceived benefits on adoption intention which actually demonstrated that the various benefits can attract and retain learners for a long time, if they are satisfied with the institutional learning services.

In order to remain competitive in the educational sector, one must change their strategies in reaching out to the potential learners and currently, all the educational institutions in the world are taking all of their services to online mode to provide the best services to the learners. A lot of new challenges will emerge over time before them such as how to provide better services, what benefits students seek, how to create adoption intention among students and what services make learners satisfied. These questions keep coming when the educational institutions start working on it, and this study will help them to understand the learners' perspective and their expectations that what benefits they seek and how their adoption intention are created and what things are needed to get satisfied.

The findings of the study will not only help to the Chhattisgarh higher education, but also all the educational institutions which are striving to know what benefits are actually turning out to students' adoption intention which further lead to student satisfaction. The COVID-19 pandemic has forced all the educational institutions to get their services online or perish over time as the WHO has also announced that COVID-19 will be among us for a long time (Jagannath, 2020).

\section{Conclusion}

Over the last decade, the use of TEL has been recorded an exponential increase, especially among the higher education students with an aim to improve their academic results (Walker et al., 2016), and in future, the usage of technologies will be much higher in order to enhance the productivity and performance in the teaching-learning process. TEL allows students to 
explore educational content in their own space and time, and it also helps to become in charge of their own learning instead of learning completely through teacher. This article examined the relationship of students' perceived benefits, adoption intention and satisfaction to TEL enrolled in different higher education in Chhattisgarh state. The outcome clearly indicated that TEL is affecting today's educational environment enormously by improving the academic results of students as the previous studies evidenced that TEL helps students in attaining the education/learning gap (Van Der Schaik, 2018).

\section{References}

Aixia, D. and Wang, D. (2011), "Factors influencing learner attitudes toward e-learning and development of e-learning environment based on the Integrated e-learning platform", International Journal of e-Education, e-Business, e-Management and e-Learning, Vol. 1 No. 3, pp. 264-268.

Ajjan, H. and Hartshorne, R. (2009), "Investigating faculty decisions to adopt Web 2.0 technologies: theory and empirical tests", The Internet and Higher Education, Vol. 11 No. 2, pp. 71-80, doi: 10. 1016/j.iheduc.2008.05.002.

Al-Azawei, A., Parslow, P. and Lundqvist, K. (2016), "Barriers and opportunities of e-learning implementation in Iraq: a case of public universities", The International Review of Research in Open and Distributed Learning, Vol. 17 No. 5, pp. 126-146.

Al-Hariri, M.T. and Al-Hattami, A.A. (2017), "Impact of students' use of technology on their learning achievements in physiology courses at the University of Dammam", Journal of Taibah University Medical School, Vol. 12 No. 1, pp. 82-85, doi: 10.1016/j.jtumed.2016.07.004.

Al-Hawari, M.A. and Mouakket, S. (2010), "The influence of technology acceptance model (TAM) factors on students' e-satisfaction and e-retention within the context of UAE e-learning", Education, Business and Society: Contemporary Middle Eastern Issues, Vol. 3 No. 4, pp. 299-314, doi: 10.1108/17537981011089596.

Al-Qirim, N., Rouibah, K., Tarhini, A., Serhani, M.A., Yammahi, A.R. and Yammahi, M.A. (2018), "Towards a personality understanding of information technology students and their IT learning in UAE university", Education and Information Technologies, Vol. 23 No. 1, pp. 29-40, doi: 10.1007/s10639-017-9578-1.

Alfraih, M.M. and Alanezi, F.S. (2016), "Accounting students' perceptions of effective faculty attributes", Journal of International Education in Business, Vol. 9 No. 2, pp. 123-142, doi: 10. 1108/JEB-04-2016-0004.

Alhumaid, K. (2019), "Four ways technology has negatively changed education", Journal of Educational and Social Research, Vol. 9 No. 4, pp. 10-20.

Arbaugh, J.B. (2005), "Is there an optimal design for online MBA courses?", Academy of Management Learning and Education, Vol. 4 No. 2, pp. 135-149.

Bagozzi, R.P. and Yi, Y. (1988), "On the evaluation of structural equation models", Journal of the Academy of Marketing Science, Vol. 16, pp. 74-94, doi: 10.1007/BF02723327.

Baloyi, G.P. (2014), "Learner support in the open distance learning and e-learning context using the community of inquiry model", Mediterranean Journal of Social Sciences, Vol. 5 No. 20, pp. 1251-1258.

Barclay, D., Higgins, C. and Thompson, R. (1995), "The partial least square (PLS) approach to casual modeling: personal computer adoption and use as an illustration”, Technology Studies, Vol. 2 No. 2, pp. 285-309.

Becker, A., Cummins, M., Davis, A., Freeman, A., Hall Giesinger, C. and Ananthanarayanan, V. (2017), NMC Horizon Report: 2017 Higher Education Edition, The New Media Consortium, Austin, Texas, TX.

Beetham, H. and Sharpe, R. (Eds) (2013), Rethinking Pedagogy for a Digital Age, Routledge, New York, NY, doi: $10.4324 / 9780203078952$.

Technologyenhanced learning 
JRIT

14,3

Bennett, J. and Bennett, L. (2003), "A review of factors that influence the diffusion of innovation when structuring a faculty training program", The Internet and Higher Education, Vol. 6 No. 1, pp. 53-63, doi: 10.1016/S1096-7516(02)00161-6.

Bhuasiri, W., Xaymoungkhoun, O., Zo, H., Rho, J.J. and Ciganek, A.P. (2012), "Critical success factors for e-learning in developing countries: a comparative analysis between ICT experts and faculty", Computers and Education, Vol. 58 No. 2, pp. 843-855, doi: 10.1016/j.compedu.2011. 10.010

Chang, S.C. and Tung, F.C. (2008), "An empirical investigation of students' behavioural intentions to use the online learning course websites", British Journal of Educational Technology, Vol. 39 No. 1, pp. 71-83, doi: 10.1111/j.1467-8535.2007.00742.x.

Chawinga, W.D. and Zozie, P.A. (2016), "Increasing access to higher education through open and distance learning: empirical findings from Mzuzu University, Malawi”, The International Review of Research in Open and Distributed Learning, Vol. 17 No. 4, pp. 1-20.

Chen, C.P., Lai, H.M. and Ho, C.Y. (2015), "Why do teachers continue to use teaching blogs? The roles of perceived voluntariness and habit", Computers and Education, Vol. 82, pp. 236-249, doi: 10. 1016/j.compedu.2014.11.017.

Cheng, Y.M. (2011), "Antecedents and consequences of e-learning acceptance", Information Systems Journal, Vol. 21 No. 3, pp. 269-299, doi: 10.1111/j.1365-2575.2010.00356.x.

Cheng, Y.M. (2014), "What drives nurses' blended e-learning continuance intention?", Educational Technology and Society, Vol. 17 No. 4, pp. 203-215.

Cheung, C.M. and Lee, M.K. (2010), "A theoretical model of intentional social action in online social networks”, Decision Support Systems, Vol. 49 No. 1, pp. 24-30, doi: 10.1016/j.dss.2009.12.006.

Chu, T.H. and Chen, Y.Y. (2016), "With good we become good: understanding e-learning adoption by theory of planned behavior and group influences", Computers and Education, Vols 92-93, pp. 37-52, doi: 10.1016/j.compedu.2015.09.013.

Chunwijitra, S., Berena, J.A., Hitoshi, O. and Haruki, U. (2013), "Advanced content authoring and viewing tools using aggregated video and slide synchronization by key marking for web-based e-learning system in higher education", IEICE Transactions on Information and Systems, Vols E96-D No. 8, pp. 1754-1765, doi: 10.1587/transinf.E96.D.1754.

Cohen, J. (1988), Statistical Power Analysis for the Behavioral Sciences, 2nd ed., Routledge, New York, NY. doi: $10.4324 / 9780203771587$.

Cullen, E. (2018), "What is Technology Enhanced Learning, and why is it important?", available at: https://www.mentimeter.com/blog/interactive-classrooms/what-is-technology-enhancedlearning-and-why-is-it-important (accessed 15 October 2020).

Davis, F.D., Bagozzi, R.P. and Warshaw, P.R. (1989), "User acceptance of computer technology: a comparison of two theoretical models", Management Science, Vol. 35 No. 8, pp. 982-1003, doi: 10. 1287/mnsc.35.8.982.

De Jong, T. and Van Joolingen, W.R. (1998), "Scientific discovery learning with computer simulations of conceptual domains”, Review of educational Research, Vol. 68 No. 2, pp. 179-201, doi: 10.3102/ 00346543068002179.

Del Barrio, S., Romero-Frías, E. and Arquero, J. (2013), "The role of e-learning satisfaction in the acceptance of technology for educational purposes: a competing models analysis", Proceedings of The Open and Flexible Higher Education Conference 2013, EADTU, European Association of Distance Teaching Universities, Paris, France, pp. 36-49.

Demiray, U. (2011), Distance Education and Elearning Practices: In Turkey And Eastern Countries, Anadolu University, Eskisehir.

Dodge, T.M., Mitchell, M.F. and Mensch, J.M. (2009), "Student retention in athletic training education programs", Journal of Athletic Training, Vol. 44 No. 2, pp. 197-207, doi: 10.4085/1062-6050-44.2.197.

Dutton, J. and Perry, J. (2002), "How do online students differ from lecture students?", Journal of Management Information Systems, Vol. 18 No. 4, pp. 169-190. 
Fishbein, M. and Ajzen, I. (1975), Belief, Attitude, Intention, and Behavior: An Introduction to Theory and Research, Addison-Wesley, Reading, Massachusetts, MA.

Fonseca, D., Martí, N., Redondo, E., Navarro, I. and Sánchez, A. (2014), "Relationship between student profile, tool use, participation, and academic performance with the use of Augmented Reality technology for visualized architecture models", Computers in Human Behavior, Vol. 31, pp. 434-445, doi: 10.1016/j.chb.2013.03.006.

Fornell, C. and Bookstein, F.L. (1982), "Two structural equation models: LISREL and PLS applied to consumer exit-voice theory", Journal of Marketing Research, Vol. 19 No. 4, pp. 440-452, doi: 10.2307/3151718.

Fornell, C. and Larcker, D.F. (1981), "Evaluating structural equation models with unobservable variables and measurement error", Journal of Marketing Research, Vol. 18 No. 1, pp. 39-50, doi: 10.1177/002224378101800104.

Garrison, D.R. (2011), E-learning in the 21st Century: A Framework for Research and Practice, Routledge, New York.

Hair, J.F., Black, W.C., Balin, B.J. and Anderson, R.E. (2010), Multivariate Data Analysis, Maxwell Macmillan International Editions, New York.

Hair, J.F., Black, W.C., Babin, B.J. and Anderson, R.E. (2013), Multivariate Data Analysis, 7th ed., Pearson Education, London.

Hayes, A.F. (2013), Introduction to Mediation, Moderation, and Conditional Process Analysis. A Regression-Based Approach, The Guilford Press, New York, NY.

Heflin, H., Shewmaker, J. and Nguyen, J. (2017), "Impact of mobile technology on student attitudes, engagement, and learning”, Computers \& Education, Vol. 107, pp. 91-99, doi: 10.1016/j.compedu. 2017.01.006.

Henderson, M., Selwyn, N., Finger, G. and Aston, R. (2015), "Students' everyday engagement with digital technology in university: exploring patterns of use and 'usefulness", Journal of Higher Education Policy and Management, Vol. 37 No. 3, pp. 308-319, doi: 10.1080/1360080X.2015. 1034424.

Henseler, J. and Chin, W.W. (2010), “A comparison of approaches for the analysis of interaction effects between latent variables using partial least squares path modeling", Structural Equation Modeling, Vol. 17 No. 1, pp. 82-109.

Henseler, J., Ringle, C.M. and Sinkovics, R.R. (2009), "The use of partial least squares path modeling in international marketing", New Challenges to International Marketing, pp. 277-319, doi: 10.1108/ S1474-7979(2009)0000020014.

Hu, X., Lin, Z., Whinston, A.B. and Zhang, H. (2004), "Hope or hype: on the viability of escrow services as trusted third parties in online auction environments", Information Systems Research, Vol. 15 No. 3, pp. 236-249.

Hui, W., Hu, P.J.H., Clark, T., Tam, K. and Milton, J. (2008), "Technology-assisted learning: a longitudinal field study of knowledge category, learning effectiveness and satisfaction in language learning", Journal of Computer Assisted Learning, Vol. 24, pp. 245-259, doi: 10.1111/j. 1365-2729.2007.00257.x.

Hulland, J. (1999), "Use of partial least squares (PLS) in strategic management research: a review of four recent studies", Strategic Management Journal, Vol. 20 No. 2, pp. 195-204, doi: 10.1002/ (SICI)1097-0266(199902)20:2\%3C195::AID-SMJ13\%3E3.0.CO;2-7.

Ifinedo, P. (2016), “Assessing students' satisfaction with blog usage for learning: focus on perceived enjoyment, knowledge sharing experience, and technology acceptance factors", In the Proceedings of the 27th IBIMA Conference, Milan, Italy, 4-5 May 2016, IBIMA Publishing LLC, King of Prussia.

Institute of Medicine (2002), Speaking of Health: Assessing Health Communication Strategies for Diverse Populations, The National Academies Press, Washington, DC. doi: 10.17226/10018.
Technologyenhanced learning 
JRIT

14,3

Jacobsen, W.C. and Forste, R. (2011), "The wired generation: academic and social outcomes of electronic media use among university students", Cyberpsychology, Behavior, and Social Networking, Vol. 14 No. 5, pp. 275-280, doi: 10.1089/cyber.2010.0135.

Jagannath, J. (2020), Covid-19 Will Be with Us for a Long Time and Be Easily Ignite: WHO, available at: https://www.livemint.com/news/world/covid-19-will-be-with-us-for-a-long-time-and-can-easilyignite-who-11587572606311.html (accessed 15 April 2021).

King, E. and Boyatt, R. (2014), "Exploring factors that influence adoption of e-learning within higher education”, British Journal of Educational Technology, Vol. 46 No. 6, pp. 1272-1280, doi: 10.1111/ bjet.12195.

Kisanga, D.H. (2016), "Determinants of teachers' attitudes towards e-learning in Tanzanian higher learning institutions", The International Review of Research in Open and Distributed Learning, Vol. 17 No. 5, pp. 109-125.

Komiak, S.Y.X., Wang, W. and Benbasat, I. (2004), "Trust building in virtual salespersons versus in human salespersons: similarities and differences”, E-service Journal, Vol. 3 No. 3, pp. 49-64, doi: 10.2979/esj.2004.3.3.49.

Lee, W.J. (2010), "Online support service quality, online learning acceptance, and student satisfaction”, Internet and Higher Education, Vol. 13 No. 4, pp. 227-283, doi: 10.1016/j.iheduc.2010.08.002.

Lee, Y. and Hsiao, C. (2014), "An empirical examination of individual and system characteristics on enhancing e-learning acceptance", Australasian Journal of Food Science and Technology, Vol. 30 No. 5, pp. 562-579.

Lee, D. and Lehto, M. (2013), "User acceptance of YouTube for procedural learning: an extension of the technology acceptance model”, Computers and Education, Vol. 61, pp. 193-208, doi: 10.1016/j. compedu.2012.10.001.

Lee, Y.H., Hsieh, Y.C. and Hsu, C.N. (2011), "Adding innovation diffusion theory to the technology acceptance model: supporting employees' intentions to use e-learning systems", Educational Technology and Society, Vol. 14 No. 4, pp. 124-137.

Liao, Y.W., Huang, Y.M. and Wang, Y.S. (2015), "Factors affecting students' continued usage intention toward business simulation games: an empirical study", Journal of Educational Computing Research, Vol. 53 No. 2, pp. 260-283, doi: 10.1177/0735633115598751.

Limayem, M. and Cheung, C.M.K. (2008), "Understanding information systems continuance. The case of internet-based learning technologies", Information and Management, Vol. 45 No. 4, pp. 227-232, doi: 10.1016/j.im.2008.02.005.

Lin, W.S., Wang, Y.J. and Chen, H.R. (2018), "A study of crowd-collaborative learning: an empirical study”, Library Hi Tech, Vol. 36 No. 4, pp. 622-635, doi: 10.1108/LHT-01-2018-0016.

Makokha, G.L. and Mutisya, D.N. (2016), "Status of e-learning in public universities in Kenya", The International Review of Research in Open and Distributed Learning, Vol. 17 No. 3, pp. 341-359.

Nunnally, J. (1978), Psychometric Theory, McGraw-Hill, New York.

Ong, C.S. and Lai, J.Y. (2006), "Gender differences in perceptions and relationships among dominants of e-learning acceptance", Computers in Human Behavior, Vol. 22 No. 5, pp. 816-829, doi: 10. 1016/j.chb.2004.03.006.

O'brien, R.M. (2007), "A caution regarding rules of thumb for variance inflation factors", Quality and Quantity, Vol. 41 No. 5, pp. 673-690, doi: 10.1007/s11135-006-9018-6.

Palys, T. (2008), "Purposive sampling", in Given, L.M. (Ed.), The Sage Encyclopedia of Qualitative Research Methods, Sage, Los Angeles, Vol. 2, pp. 697-698, doi: 10.4135/9781412963909.n349.

Park, S.Y. (2009), "An analysis of the technology acceptance model in understanding university students' behavioral intention to use e-learning", Educational Technology and Society, Vol. 1 No. 3, pp. 150-162.

Patterson, B. and McFadden, C. (2009), "Attrition in online and campus degree programs", Online Journal of Distance Learning Administration, Vol. 12 No. 2, pp. 1-9. 
Queiros, D.R. and de Villiers, M.R. (2016), "Online learning in a South African higher education institution: determining the right connections for the student", The International Review of Research in Open and Distributed Learning, Vol. 17 No. 5, pp. 165-185.

Roca, J.C., Chiu, C.M. and Martinez, F.J. (2006), "Understanding e-learning continuance intention: an extension of the technology acceptance model", International Journal of Human Computer Studies, Vol. 64 No. 8, pp. 683-696, doi: 10.1016/j.ijhcs.2006.01.003.

Rogers, E.M. (1995), Diffusion of Innovation, 4th ed., Free Press, New York, NY.

Salloum, S.A.S. and Shaalan, K. (2018), 'Investigating students' acceptance of E-learning system in higher educational environments in the UAE: applying the extended technology acceptance model (TAM)", Dissertation, The British University in Dubai Digital Depository.

Sandars, J. (2012), “Technology-enhanced learning”, Education for Primary Care, Vol. 23 No. 2, pp. 137-138, doi: 10.1080/14739879.2012.11494089.

Saye, J.W. and Brush, T. (2007), "Using technology-enhanced learning environments to support problem-based historical inquiry in secondary school classrooms", Theory and Research in Social Education, Vol. 35 No. 2, pp. 196-230, doi: 10.1080/00933104.2007.10473333.

Seddon, P.B. (1997), "A respecification and extension of the De Lone and McLean model of IS success", Information Systems Research, Vol. 8 No. 3, pp. 240-253, doi: 10.1287/isre.8.3.240.

Shrout, P.E. and Bolger, N. (2002), "Mediation in experimental and nonexperimental studies: new procedures and recommendations", Psychological Methods, Vol. 7 No. 4, pp. 422-445, doi: 10. 1037/1082-989X.7.4.422.

Sife, A., Lwoga, E. and Sanga, C. (2007), "New technologies for teaching and learning: challenges for higher learning institutions in developing countries", International Journal of education and Development Using ICT, Vol. 3 No. 2, pp. 57-67.

Stone, R.W. and Baker-Eveleth, L. (2013), "Students' expectation, confirmation, and continuance intention to use electronic textbooks", Computers in Human Behavior, Vol. 29 No. 3, pp. 984-990, doi: 10.1016/j.chb.2012.12.007.

Sun, P.C., Tsai, R., Finger, G., Chen, Y.Y. and Yeh, D. (2008), "What drives a successful e-learning? An empirical investigation of the critical factors influencing learner satisfaction", Computers and Education, Vol. 50 No. 4, pp. 1183-1202, doi: 10.1016/j.compedu.2006.11.007.

Sun, P.C., Tsai, R.J., Finger, G., Chen, Y.Y. and Yeh, D. (2008), "What drives a successfule-learning? An empirical investigation of the critical factors influencing learner satisfaction", Computers and Education, Vol. 50 No. 4, pp. 1183-1202, doi: 10.1016/j.compedu.2006.11.007.

Sweeney, J.C. and Ingram, D. (2001), “A comparison of traditional and web-based tutorials in marketing education: an exploratory study", Journal of Marketing Education, Vol. 23 No. 1, pp. 55-62.

Tang, J.E., Tang, T. and Chiang, C. (2014), "Blog learning: effects of users' usefulness and efficiency towards continuance intention", Behaviour and Information Technology, Vol. 33 No. 1, pp. 36-50, doi: 10.1080/0144929X.2012.687772.

Tarhini, A., Hone, K. and Liu, X. (2014), "The effects of individual differences on e-learning users' behaviour in developing countries: a structural equation model", Computers in Human Behavior, Vol. 41, pp. 153-163, doi: 10.1016/j.chb.2014.09.020.

Tarhini, A., Masa'deh, R.E., Al-Busaidi, K.A., Mohammed, A.B. and Maqableh, M. (2017), "Factors influencing students' adoption of e-learning: a structural equation modeling approach", Journal of International Education in Business, Vol. 10 No. 2, pp. 164-182, doi: 10.1108/JIEB-092016-0032.

Taylor, P.S. (2007), "Can clickers cure crowded classes? Students love the new gadgets, even if they mean more pop quizzes”, Maclean's, Vol. 120 No. 26, p. 73.

Tetteh, G.A. (2016), "Effects of business school student's study time on the learning process", Journal of International Education in Business, Vol. 9 No. 2, pp. 90-110, doi: 10.1108/JIEB-06-2016-0012.
Technologyenhanced learning

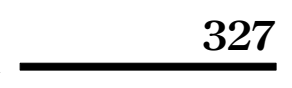


JRIT

14,3

Thomas, P.Y. (2011), "Cloud computing: a potential paradigm for practicing the scholarship of teaching and learning", The Electronic Library, Vol. 29 No. 2, pp. 214-224, doi: 10.1108/ 02640471111125177.

Tiyar, F.R. and Khoshsima, H. (2015), "Understanding students' satisfaction and continuance intention of e-learning: application of expectation-confirmation model”, World Journal Educational Technology: Current Issues, Vol. 7 No. 3, pp. 157-166, doi: 10.18844/wjet.v7i3.203.

Tomei, L.A. (2005), Taxonomy for the Technology Domain, Information Science Publishing, Pennsylvania.

Truong, Y. and McColl, R. (2011), "Intrinsic motivations, self-esteem, and luxury goods consumption", Journal of Retailing and Consumer Services, Vol. 18 No. 6, pp. 555-561, doi: 10.1016/j.jretconser. 2011.08.004.

Turban, E., King, D., Lee, J.K., Liang, T.P. and Turban, D.C. (2015), "Electronic commerce: a managerial and social networks perspective", Springer Texts in Business and Economics.

Van Der Schaik, J. (2018), “Can e-learning bridge Africa's education gap?”, available at: https:// freedomlab.org/can-e-learning-bridge-africas-education-gap/ (accessed 3 May 2020).

Wadhwani and Gankar (2020), "e-learning market size by technology (e-Learning, learning management system (LMS), mobile e-learning, rapid e-learning, virtual classroom), by provider (service, content), by application (academic [K-12, higher education, vocational training], corporate (SMBs, large enterprises], government), industry analysis report, regional outlook, Growth potential, competitive market share and forecast, 2020-2026”, Global Market Insights, pp. 1-270.

Walker, R., Voce, J., Swift, E., Ahmed, J., Jenkins, M. and Vincent, P. (2016), 2016 Survey of Technology Enhanced Learning for Higher Education in the UK, Universities and Colleges Information Systems Association, Oxford.

Wu, H., Tennyson, R.D. and Hsia, T. (2010), "A study of student satisfaction in a blended e-learning system environment”, Computers and Education, Vol. 55 No. 1, pp. 155-164, doi: 10.1016/j. compedu.2009.12.012.

\section{Further reading}

Jones, P. and Relf, S. (2004), in McLeod, S. (Ed.), "Adventures in multiliteracies: negotiating pedagogic relations in an online era", Proceedings of the 2004 ATEA National Conference, Australian Teacher Education Association, pp. 359-367.

Relf, S. (2007), Online l(IT)eracy Practices: Case Studies in Writing Online Distance Education Study Materials, Unpublished Master Thesis, University of Technology Sydney, Sydney.

\section{Corresponding author}

Kailash Kumar Sahu can be contacted at: mailtokailashsahu@gmail.com

For instructions on how to order reprints of this article, please visit our website:

www.emeraldgrouppublishing.com/licensing/reprints.htm

Or contact us for further details: permissions@emeraldinsight.com 